OPEN ACCESS

Edited by: Hong Chen,

Boston Children's Hospital, USA

Reviewed by:

Jun Yu,

Temple University, USA Jiliang Zhou,

Georgia Health Sciences

University, USA

*Correspondence: Shi-You Chen

sc229@uga.edu

tThese authors have contributed equally to this work.

Specialty section: This article was submitted to Atherosclerosis and Vascular Medicine,

a section of the journal Frontiers in Cardiovascular Medicine

Received: 31 March 2017 Accepted: 01 May 2017 Published: 22 May 2017

Citation:

Li F, Guo X and Chen S-Y (2017)

Function and Therapeutic Potential of Mesenchymal Stem Cells in Atherosclerosis.

Front. Cardiovasc. Med. 4:32. doi: 10.3389/fCvm.2017.00032

\section{Function and Therapeutic Potential of Mesenchymal Stem Cells in Atherosclerosis}

\author{
Feifei $\mathrm{Li}^{1,2 t}, \mathrm{Xia} \mathrm{Guo}^{1 \dagger}$ and Shi-You Chen ${ }^{1 *}$ \\ ${ }^{1}$ Department of Physiology \& Pharmacology, University of Georgia, Athens, GA, USA, ${ }^{2}$ The Department of Cardiovascular \\ Surgery, Union Hospital, Wuhan, China
}

Atherosclerosis is a complicated disorder and largely attributable to dyslipidaemia and chronic inflammation. Despite therapeutic advances over past decades, atherosclerosis remains the leading cause of mortality worldwide. Due to their capability of immunomodulation and tissue regeneration, mesenchymal stem cells (MSCs) have evolved as an attractive therapeutic agent in various diseases including atherosclerosis. Accumulating evidences support the protective role of MSCs in all stages of atherosclerosis. In this review, we highlight the current understanding of MSCs including their characteristics such as molecular markers, tissue distribution, migratory property, immune-modulatory competence, etc. We also summarize MSC functions in animal models of atherosclerosis. MSC transplantation is able to modulate cytokine and chemokine secretion, reduce endothelial dysfunction, promote regulatory $T$ cell function, decrease dyslipidemia, and stabilize vulnerable plaques during atherosclerosis development. In addition, MSCs may migrate to lesions where they develop into functional cells during atherosclerosis formation. Finally, the perspectives of MSCs in clinical atherosclerosis therapy are discussed.

Keywords: atherosclerosis, mesenchymal stem cells, characteristics, functional properties, therapeutics

\section{INTRODUCTION}

Atherosclerosis, a vascular disorder leading to occlusion of the arterial wall, causes several important complications including coronary and cerebral artery diseases $(1,2)$. Smoking, hypertension, diabetes, and dyslipidemia are well-known risk factors for atherosclerosis $(3,4)$. Despite the effective treatment targeting serum lipid abnormalities, atherosclerosis remains a leading cause of mortality $(1,5)$. The pathophysiological mechanisms of atherosclerosis are very complex and involve accumulation of lipoprotein aggregates in the subendothelial space, inflammatory responses of vascular endothelial cells (ECs), adhesion and infiltration of monocytes, and transformation of macrophages into foam cells induced by oxidized low-density lipoprotein (ox-LDL) (6-9). In fact, atherosclerosis is a chronic inflammatory disease involving both innate and adaptive immunity. Pattern recognition receptors of innate immunity regulate cholesterol uptake and contribute to the foam cell formation and EC dysfunction (10). Antigen-specific T cells recognizing LDL in the intima are the adaptive immunity components in the development of atherosclerosis and provoke pro-inflammatory stimuli that further exacerbate and propagate this disease (11). Therefore, strategies to mobilize and stimulate immunosuppression may provide novel therapeutic approaches to reduce atherosclerotic cardiovascular disease $(12,13)$.

Cell therapy has been a focus for intense research and already being used widely for the treatment of various diseases. Mesenchymal stem cells (MSCs), also referred to as multipotent stromal cells, are 
a class of multipotent stem cells that can be isolated from various tissues including bone marrow, peripheral blood, adipose, placenta, etc. (14-16). MSCs have been explored as an attractive therapeutic agent in various diseases and injury models including acute lung injury, myocardial infarction, acute renal failure, cerebral ischemia, Alzheimer's disease, and corneal damage (14, 17-22), due to their capabilities of differentiation into multiple cell lineages such as mesodermal lineage (adipocyte, osteoblast, chondrocyte) and myogenic lineage $(15,23)$. The interests in MSCs have been further enhanced by their advantages over other stem cell populations including their low immunogenicity, easy cultivation, and expansion in vitro. Moreover, recent studies reveal the anti-inflammatory properties of MSCs as guardians of inflammation (24). In view of the critical role of inflammatory processes in the initiation and progression of atherosclerosis, adoptive transfer of MSCs, which has the capability to modulate and reduce inflammation, may be a novel therapeutic approach to treat atherosclerosis. Understanding of the activities and functions of MSCs in different atherosclerotic animal models and mechanisms underlying their therapeutic effects may be important for further investigation into its potential clinical application.

\section{CHARACTERISTICS OF MSCs}

\section{Tissue Sources, Isolation, and Expansion of MSCs}

Mesenchymal stem cells have been found in almost all tissues/ organs and can be derived from a variety of different sources, including adult peripheral blood, adipose tissue, and bone marrow, as well as fetal tissues, e.g., umbilical cord blood, Wharton's jelly, amnion, amniotic fluid, and placenta (16). Currently, most MSCs used for clinical trials are isolated from bone marrow, adipose tissue, and umbilical cord blood (25). Bone marrowderived mesenchymal stem cells (BM-MSCs) first described by Friedenstein et al. are the most frequently investigated cell type and often considered as the gold standard (26). However, the procedure for bone marrow aspirate is highly invasive for patients and accompanied by a risk of infection. Moreover, the limited accessibility is coupled with a relatively low cell yield (0.001-0.01\%) and a substantial reduction in the expansibility of the cells in aged populations (27). Therefore, alternative sources of MSCs have been studied for their biological properties, differentiation capacities, and surface marker expression. The second major source of MSCs is adipose tissue-derived stem cells (AT-MSCs). AT-MSCs are normally isolated from biological materials generated during liposuction, lipoplasty, or lipectomy procedures. These cells share many biological characteristics with BM-MSCs (28). Although the colony frequency of cells obtained from adipose tissues is higher than those of bone marrow, there is controversy on whether AT-MSCs are truly MSCs, as they are often named as "adipose tissue stem cells" $(29,30)$. Embryonic tissues are also important sources for MSC isolation. MSCs from the embryonic tissues have superior biological properties compared with BM-MSCs (16). They also have improved proliferative capacity, life span, and differentiation potential compared with MSCs derived from adult tissues (16).
Several different procedures have been used to isolate MSCs from different tissues. The commonly applied methods for preparing BM-MSCs or MSCs derived from umbilical cord blood (UBC-MSCs) utilize density gradient isolation or direct plating to separate mesenchymal from hematopoietic cells by their adhesion capacities to the plastic surface (31). Seeding densities are very important for successfully expanding MSCs. Accordingly, plating densities of $4-22 \times 10^{3}$ bone marrow mononuclear cells $/ \mathrm{cm}^{2} \mathrm{can}$ yield up to $9.8 \times 10^{8}$ MSCs when they are harvested after one passage (32). The UBC-MSCs fraction is suggested to be seeded at a higher density of $1 \times 10^{6} / \mathrm{cm}^{2}$ due to their low frequency (29). To isolate MSCs from adipose tissue, enzymatic treatment is commonly used. Centrifugation is performed to acquire the preadipocyte stromal vascular fraction, and the adipocyte fraction is removed. After culture for 10 days, approximately 1:1,000 cells within the stromal vascular fraction will generate colonyforming units (29).

\section{Validation of MSC Identity}

Mesenchymal stem cells are identified by a combination of phenotypic and functional characteristics. In line with the International Society for Cellular Therapy, MSCs must be plastic adherent under basic culture conditions and able to differentiate to adipocytes, chondrocytes, and osteoblasts in vitro. Numerous publications have suggested minimal criteria of several stem cell markers to categorize MSCs, including the positive expression of CD29, CD44, CD73, CD90, and CD105 and the negative expression of hematopoietic markers (CD14, CD34, CD45), endothelial markers (CD31), human leukocyte antigen (HLA) class II, costimulatory molecules (CD80, CD86), and HLA-DR surface molecules (33-35). These biomarkers constitute a uniform characterization of MSCs and enable the comparison of different studies. However, some of these markers may be lost, or new markers may arise during culture process. The markers may also vary between different sources. For example, fibroblastderived MSCs express CD34 and CD45 surface markers, which are absent in BM-MSCs (36). UBC-MSCs showed CD45, CD14, and CD31 positive and CD34, CD1a, and CD80 negative, which are quite different from that of the BM-MSCs (37-39).

\section{Distribution and Migration of MSCs}

Mesenchymal stem cells are increasingly used as an intravenously administered cellular therapy due to their characteristics of migration to the site of injury. To track the distribution of MSCs in vivo, various methods of labeling have been used, including radioactive labeling, fluorescent vital dyes, contrast agents, transduction with reporter genes, and the use of donor cell-specific DNA markers such as microsatellites (40-44). By using these approaches, MSCs are found to migrate to a variety of tissues after the intravenous injection although low or very low frequencies of MSCs are detectable in these tissues (45). Early after administration of the MSCs, signals from the injected cells are found at the highest frequencies in the lung followed by liver and spleen $(46,47)$. Due to the limitation of technologies detecting transplanted cells, there is only limited evidence indicating that the MSCs migrate as intact cells into their target locations. Intravenously injected MSCs have been observed to accumulate in tissues of myocardial ischemia, and 
adhesion molecules very late antigen- 4 and vascular cell adhesion molecule-1 appear to be involved in the migration (48-50). Moreover, an increased level of CC-chemokine ligand (CCL)-2 has been shown to facilitate the accumulation of MSCs in heart (51). In murine stroke model, MSCs migrate into ischemic areas after intravenous delivery, which involves the endothelial expression of P- and E-selectin (52). Apparently, the route of administration is critical for the efficiency of MSC therapy. Compared with the intravenous route, intra-arterial route of administration is more effective in avoiding pulmonary entrapment of MSCs, and may thus improve the biodistribution and bioavailability of transplanted MSCs to clinically relevant tissues $(53,54)$.

\section{Immunomodulatory Properties of MSCs}

A number of studies have confirmed the immunosuppressive function of MSCs. MSCs have been used to treat severe graftversus-host disease based on the fact that MSCs can alter several properties of $\mathrm{T}$ cells. The most prominent one is to efficiently suppress the proliferation of the activated $\mathrm{CD} 4^{+} \mathrm{T}$ helper cells and $\mathrm{CD}^{+}$cytotoxic $\mathrm{T}$ cells $(55,56)$. Indoleamine-pyrrole-23-dioxygenase (IDO), an intracellular enzyme, is the primary mediator of MSC immunomodulatory activity. IDO has been shown to reduce immune cell proliferation by regulating tryptophan depletion and accumulating metabolites such as kynurenine $(57,58)$. MSCs are also known to halt B-cell maturation in G0/G1 phase and simultaneously diminish their chemotactic activity. In addition, MSCs can block the maturation of dendritic cells (DCs), resulting in a reduced expression of antigens and costimulatory molecules necessary for activating T-cells (59). Moreover, MSCs are found to downregulate the activating receptors of natural killer (NK) cells NKp30, NKp44, and NKG2D (60).

Several studies suggest that MSCs alter the cytokine secretion profile of immune cells including DCs, naive and effector T cells, and NK cells (61). Indeed, MSCs can reduce tumor necrosis factor $\alpha$ (TNF- $\alpha)$ secretion from mature DCs type 1 (DC1), increase interleukin 10 (IL-10) secretion from mature DC2, decrease Interferon gamma (IFN- $\gamma$ ) secretion from NK cells and Th 1 cells, and increase IL- 4 from Th2 cells. In addition, MSCs inhibit the production of IL-17, IL-22, IFN- $\gamma$, and TNF- $\alpha$ by preventing the differentiation of naive $\mathrm{CD} 4^{+} \mathrm{T}$ cells into Th17 cells in vitro (62). Moreover, BM-MSCs decrease the production of proinflammatory cytokines IFN- $\gamma$, TNF- $\alpha$, and IL- 2 in T and B lymphocytes and suppress cell proliferation (63). MSCs have also been shown to secrete tumor necrosis factor alpha-stimulated gene-6 (TSG-6), a powerful anti-inflammatory factor (18). Tolllike receptors (TLRs) such as TLR3 and TLR4 are abundantly expressed in MSCs, and their activation regulates MSC antiinflammatory functions (64).

\section{FUNCTION OF MSCs IN ATHEROSCLEROSIS}

\section{The Pathophysiological Mechanisms of Atherosclerosis}

Atherosclerosis has traditionally been considered as a metabolic disorder caused by hyperlipidemia and fatty deposits and a chronic inflammatory disease of the arterial wall (12). Inflammation plays a crucial role in every stage of atherosclerosis from initial onset of the plaque to rupture. Early in the disease process, entrapped ox-LDL in the vessel wall leads to arterial endothelial dysfunction and an upregulation of leukocyte adhesion molecules such as selectins, integrins, and immunoglobulin proteins, which induce inflammatory cell adhesion, rolling, and migration to subendothelial region (65-67). Thereafter, monocytes, T cells, and neutrophils infiltrate through gaps between interendothelial junctions. The monocyte-derived macrophages and DCs engulf lipid molecules and then become foam cells, and simultaneously produce an array of inflammatory cytokines (68). Accumulation of immune cells and lipid droplets in the intima result in the early plaque, known as fatty steak. In the center of a mature plaque, foam cells and extracellular lipid droplets form a core region surrounded by a cap of smooth muscle cells (SMCs) and a collagen-rich matrix (7). Both macrophages and DCs express TLRs to mediate the activation of antigen-presenting cells and production of inflammatory cytokines. $\mathrm{CD} 4^{+} \mathrm{T}$ cells are crucially involved in the development of atherosclerosis, and their depletion reduces the lesion size by $70 \%$ (69). The predominant $\mathrm{T}$ cell subset in human and murine atherosclerotic lesions is the Th1 subset, which produces a number of inflammatory cytokines such as IFN- $\boldsymbol{\gamma}(70,71)$. IFN- $\boldsymbol{\gamma}$ promotes vascular inflammation by enhancing maturation and activation of antigen-presenting cells, increasing macrophage lipid uptake, reducing collagen production by phenotypically modulated SMCs, and enhancing expression of endothelial adhesion molecules to facilitate leukocyte recruitment to the lesions (72). The continuous recruitment of leukocytes to atherosclerotic arteries leads to a feed-forward promotion of inflammatory cycle.

Due to the essential role of inflammation in the initiation and progression of atherosclerosis, MSCs transplantation, which has the capacity to modulate and reduce inflammation, has been broadly explored as a therapeutic approach to treat atherosclerosis. The notable characteristics of allogeneic MSCs, such as low immunogenicity, inhibition of $\mathrm{T}$ cell proliferation, and memory T cell responses, make allogeneic MSCs transplantation an attractive approach $(56,73,74)$. Multiple studies have demonstrated that MSCs exhibit atheroprotective effects in animal atherosclerosis, mostly induced by high-fat diet in apolipoprotein $\mathrm{E}$ (ApoE) or low-density lipoprotein receptor (LDLR) knockout mice. In most of these studies, MSCs are derived from bone marrow although umbilical cord blood-derived MSCs and skin-derived MSCs (S-MSCs) are also used (Table 1).

\section{MSCs Modulate Cytokine and Chemokine Secretion during Atherosclerosis Development}

The protective effects of MSCs in animal atherosclerosis models are mainly attributable to its production of a number of anti-inflammatory factors. The application of BM-MSCs in atherosclerotic mouse causes an increased secretion of anti-inflammatory cytokines such as transforming growth factor (TGF)- $\beta 1$ and IL-10, and the decreased production of 
TABLE 1 | Mesenchymal stem cell (MSC) treatments against atherosclerosis in animal models.

\begin{tabular}{|c|c|c|c|c|}
\hline Reference & MSCs sources/dose & Route & Animal model & Mechanism of MSC action \\
\hline Fang et al. (75) & $\begin{array}{l}\text { Bone marrow } \\
1 \times 10^{7} \text { cells }\end{array}$ & $\begin{array}{l}\text { Allogeneic } \\
\text { Intra-arterial }\end{array}$ & New Zealand rabbits & $\begin{array}{l}\text { PAl-1, hs-CRP, MMPs } \downarrow \\
\text { Collagen fibers } \uparrow\end{array}$ \\
\hline Wang et al. (76) & $\begin{array}{l}\text { Bone marrow } \\
10^{7} \text { cells }\end{array}$ & $\begin{array}{l}\text { Allogeneic } \\
\text { Intravenous }\end{array}$ & $\mathrm{ApoE}^{-/-}$mice & $\begin{array}{l}\mathrm{CD}^{+}{ }^{+} \mathrm{CD} 25^{+} \mathrm{FOXP}^{+} \text {Tregs } \uparrow \\
\mathrm{CD} 36, \mathrm{SRA} \downarrow\end{array}$ \\
\hline Lin et al. (77) & $\begin{array}{l}\text { Bone marrow } \\
2 \times 10^{5} \text { cells }\end{array}$ & $\begin{array}{l}\text { Allogeneic } \\
\text { Intravenous }\end{array}$ & ApoE $^{-/-}$mice & IL8, MIP-2, eNOS $\uparrow$ \\
\hline Frodermann et al. (78) & $\begin{array}{l}\text { Bone marrow } \\
0.5 \times 10^{6} \text { cells }\end{array}$ & $\begin{array}{l}\text { Allogeneic } \\
\text { Intravenous }\end{array}$ & $\mathrm{LDLR}^{-/-}$mice & $\begin{array}{l}\text { Circulating monocytes } \downarrow \\
\text { CD4 }+ \text { T cells, CCL2, IFN- } \gamma \downarrow \\
\text { TNF- } \alpha \text {, serum cholesterol level } \downarrow \\
\text { Tregs } \uparrow\end{array}$ \\
\hline Wang et al. (79) & $\begin{array}{l}\text { Bone marrow } \\
1 \times 10^{7} \text { cells }\end{array}$ & $\begin{array}{l}\text { Allogeneic } \\
\text { Intravenous }\end{array}$ & New Zealand rabbits & $\begin{array}{l}\text { hs-CRP, TNF- } \alpha, \text { IL-6, NF- } \kappa B \downarrow \\
\text { MMPs, cell apoptosis } \downarrow \\
\text { TSG-6, IL-10 }\end{array}$ \\
\hline Abdel-Kawi and Hashem (80) & $\begin{array}{l}\text { Cord blood } \\
3 \times 10^{6} \text { cells }\end{array}$ & $\begin{array}{l}\text { Allogeneic } \\
\text { Intravenous }\end{array}$ & Albino rats & iNOS $\uparrow$ \\
\hline Li et al. (81) & Skin & $\begin{array}{l}\text { Allogeneic } \\
\text { Intravenous }\end{array}$ & $\mathrm{ApoE}^{-/-}$mice & $\begin{array}{l}\mathrm{PGE} 2, \mathrm{IL}-10 \uparrow \\
\mathrm{TNF}-\alpha, \mathrm{NF}-\kappa \mathrm{B} \downarrow\end{array}$ \\
\hline
\end{tabular}

pro-inflammatory cytokines, such as TNF- $\alpha$, IL- $1 \beta$, and IL-6 (76). TGF- $\beta 1$ is involved in the MSC-mediated induction of $\mathrm{CD}^{+} \mathrm{CD} 25^{+} \mathrm{Foxp}^{+}$regulatory $\mathrm{T}$ cells (Tregs) (82) and the decreased proliferation of NK cells (83). IL-10 exerts its antiatherogenic effects primarily by influencing the local inflammatory process within the lesion through inhibiting macrophage activation, matrix metalloproteinase, and pro-inflammatory cytokines $(65,84)$. Frodermann et al. have found that MSC therapy significantly reduces serum CCL2 levels, a chemokine that attracts and activates mononuclear cells (78). In addition, MSC treatment results in an overall reduced inflammatory state as well as a significant reduced differentiation of naive $\mathrm{T}$ cells. Similarly, treatment with skin-derived MSCs (S-MSCs) reduces the release of TNF- $\alpha$ and increases the expression of IL-10 both in vivo and in vitro, which is both dependent on NF- $\mathrm{\kappa B}$ activation (81). There is a reduced expression of NF- $\kappa \mathrm{B}$ in atherosclerotic plaque after MSC transplantation (79). These findings are consistent with many other studies showing that MSCs can inhibit the expression and activity of NF- $\mathrm{BB}(85-87)$.

Mesenchymal stem cell activation also leads to the production and release of modulation of target molecules including IDO, prostaglandin E2 (PGE2), and TSG-6 (88). IDO inhibits Th17 differentiation through an exhaustion of tryptophan (58). Moreover, IDO decreases the proliferation and cytotoxic activity of NK cells activated by IL- 2 in the presence of MSCs and inhibits the maturation and functional activity of DCs (89). PGE2 has been shown to diminish $\mathrm{T}$ cell proliferation, stimulate IL-4 and IL-10 secretion, and promote $\mathrm{CD} 4^{+} \mathrm{CD} 25^{+} \mathrm{Foxp} 3^{+}$Tregs differentiation (90). TSG-6 is not constitutively expressed in normal tissues or cells, but is upregulated in response to pro-inflammatory cytokines such as TNF- $\alpha$, IL-1, and IL-6 $(91,92)$. TSG-6 facilitates a feedback mechanism to inhibit inflammation-mediated extracellular matrix remodeling by reducing inflammatory factor expression and inhibiting neutrophil infiltration and plasmin activity $(93,94)$.

\section{MSCs Improve Endothelial Function during the Development of Atherosclerosis}

Endothelial dysfunction is one of the earliest events of atherosclerosis, resulting in subsequent lipid accumulation, macrophage recruitment, foam cells formation, and $\mathrm{T}$ cell and platelet recruitment (95). In addition to providing a lining for vessel walls, the endothelium is a complex endocrine and paracrine organ that plays a crucial role in the maintenance of vascular homeostasis. Endothelial nitric oxide synthase (eNOS) is responsible for the production of most vascular nitric oxide (NO) $(96,97)$. NO acts as a local vasodilator by increasing smooth muscle cyclic guanosine monophosphate (cAMP) levels while inhibiting leukocyte adhesion and activation, platelet aggregation, and SMC proliferation. NO also has anti-inflammatory properties by inhibiting the expression of leukocyte adhesion molecules (98). Although ECs have the potential to self-repair in response to inflammatory stimuli, MSCs appear to be able to accelerate the repairing process. For example, amnion-derived MSCs have been reported to enhance EC viability as shown by decreasing lactate dehydrogenase level and stabilize the endothelial network formation in vitro (99). Lin et al. demonstrated that allogeneic BM-MSCs transplantation attenuates atherosclerosis through repairing the diseased endothelium and improving endothelial function (77). ox-LDL deactivates Akt/eNOS activity, induces eNOS degradation, and thus inhibits NO production in EC. However, coculture with human MSCs reverses the effects of ox-LDL on ECs. It appears that the protective effect of MSCs on EC activation of the Akt/eNOS pathway is achieved mainly through upregulation of IL8 and macrophage inflammatory protein (MIP)-2. The effects of human/mouse MSCs on ox-LDLtreated ECs are blocked by the neutralization antibodies against IL8/MIP-2. Therefore, MSC transplantation could ameliorate atherosclerosis by improving endothelial function and plaque formation. 


\section{MSCs Increase the Quantity and Enhance the Function of Tregs during Atherosclerosis Development}

Regulatory T cells have been shown to exert an immunosuppressive function through producing inhibitory cytokines such as IL-10 and TGF- $\beta$. Tregs mediate cell-cell contact by membranebound TGF- $\beta$ and cytotoxic T lymphocyte-associated antigen $(100,101)$. Tregs are initially characterized as CD $4^{+} \mathrm{CD} 25^{+} \mathrm{T}$ cells. However, later studies identify forkhead box transcription factor (FOXP3) as a key lineage protein and a master regulator in Treg development and function (102-104). In atherosclerotic plaques, there is a low number of FOXP3 ${ }^{+}$Tregs $(105,106)$. Knockdown of FOXP3 promotes the progression of atherosclerosis in mice (106, 107), suggesting a possible atheroprotective function of $\mathrm{FOXP}^{+}$Tregs. Transplantation experiments in immunedeficient, hyperlipidemic mice demonstrate that Tregs exert their atheroprotective role by repressing the function of DCs and Th1/ Th2 cells (108). Mechanistic analyses reveal that IL-10 and TGF$\beta$, the two major cytokines produced by Tregs, suppress functions of DCs and Th1/Th2 cells in atherosclerosis (109-112). In addition, Tregs are able to repress the expression of the matrix metalloproteinases MMP-2 and MMP-9, two important proteinases degrading extracellular matrix proteins, and thus enhance the lesion stability in atherosclerosis mouse model $(107,108,113)$.

The major obstacle associated with Treg treatment is the inability to efficiently isolate a pure population of Tregs. There are no validated cell surface markers that can be used for cell sorting. A promising alternative is to use MSCs. MSCs can recruit and promote the generation of Tregs $(75,88)$. Indeed, MSC treatment has significantly increased the number and function of Tregs in cultured splenocytes. It also increases the mRNA and protein expression of FOXP3 in atherosclerotic mouse model (76). It is also reported that $\mathrm{ApoE}^{-1-}$ mice treated with multiple times and high numbers $\left(10^{7}\right)$ of MSCs can dramatically reduce the longterm overall loading of effector T cells, which is partially due to the lasting increase of Tregs. Several mechanisms underlie the MSC-induced expansion of Tregs. Soluble factors are proved to be involved while cell-cell contact is also vital. MSCs are able to induce Tregs by directly contacting with $\mathrm{CD} 4^{+} \mathrm{T}$ cells (82). Melief et al. have also reported that MSCs increase TGF- $\beta 1$ secretion to promote the generation of Tregs (114). Further study reveals that the increased gene expression of the Notch ligand, Delta-like 1, is essential for the augmented Tregs induction by TLR-activated MSCs, which is dependent on cell-cell contact (64). Notch ligand Jagged-1 is also involved in MSC induction of Tregs (115). In addition, the presence of monocytes is important for the MSCinduced generation of Tregs as well. MSCs promote monocyte survival and induce monocytes to differentiate toward an antiinflammatory type 2 macrophage phenotype, which mediates Tregs formation by the production of CCL18 (114).

\section{MSCs Can Migrate to Lesions and Develop into Functional Cells during Atherosclerosis Development}

The intrinsic ability of MSCs to differentiate into functional cell types enables them to repair the diseased or injured tissues in which they are localized. The carboxyfluorescein succinimidyl ester-labeled mMSCs are found in areas close to the endothelium at 7 days after the injection while S-MSCs migrate to atherosclerotic plaque and selectively take up residence near macrophages $(77,81)$. The transplanted BM-MSCs are able to "home in" on the ruptured plaque regions and differentiate into ECs and collagen fibers (75). BrdU-labeled BM-MSCs are observed in ruptured plaques 4 weeks after the MSC transplantation. The mechanisms regulating stem cell differentiation and their mobilization or migration to the site of vascular injury involve several mediators and receptors, such as P-selectin glycoprotein ligand-1, $\alpha 4$ integrin, CXC chemokine receptor- 2 and -4 , and $\beta 1$ - and $\beta 2$-integrins $(116,117)$. In addition, the interaction of platelets with progenitor cells also influences MSC chemotaxis, adhesion, activation, and differentiation into mature ECs during vascular repair (118).

\section{MSCs Reduce Dyslipidemia during the Development of Atherosclerosis}

Dyslipidemia is a major risk factor for the development and progression of atherosclerosis (119). MSCs appear to have indirect effects on cholesterol metabolism through immune modulation. The connection between immune cells and cholesterol metabolism has been established. Both $\mathrm{ApoE}^{-/-}$mice on chow diet and $\mathrm{LDLR}^{-/-}$mice on high-fat diet lacking both $\mathrm{B}$ and $\mathrm{T}$ cells show reduced plasma lipoproteins, especially the apoB-containing lipoproteins (120). MSCs treatment not only suppresses inflammatory responses but also significantly lowers the plasma cholesterol levels in MSC-treated mice due to a reduction of VLDL levels after a 5-week treatment (78). In MSC-treated mice, a significant decrease of lipoprotein lipase is observed in liver, which reduces the availability of free fatty acids for VLDL synthesis. MSC-treated mice also exhibit a reduced VLDL metabolism due to the reduced activation of Kupffer cells. Kupffer cells can express mediators promoting VLDL secretion by hepatocytes (121). Moreover, lipoprotein lipase deficiency in macrophages reduces their uptake of VLDL or ox-LDL, thereby attenuating atherosclerosis $(122,123)$. Overall, MSCs reduce VLDL levels by decreasing inflammation. Indeed, TNF- $\alpha$ that is downregulated in MSC and splenocyte coculture has been shown to upregulate SREBP-1c, which increases VLDL synthesis (124). Conversely, IL-10 overexpression reduces plasma cholesterol, mostly due to a reduced VLDL, in $\mathrm{LDLR}^{-/-}$mice (125).

\section{MSCs Enhance Stability of Advanced Atheroslerotic Lesions}

Atherosclerotic plaques are able to alternate between stable and vulnerable states depending on the internal environment. It is generally believed that lesions with a thin fibrous cap, large lipid core, and a large number of macrophages are unstable and prone to rupturing. Rupture and embolism of the atherosclerotic plaque lead to acute coronary syndrome and ischemic stroke $(126,127)$. Clinical evidence indicates that the instability rather than the plaque size determines the prognosis of cardiovascular diseases $(128,129)$. Recently, allogeneic MSCs have been evaluated for their potential to repair ruptured lesions. It appears that MSCs can increase the regeneration of the inner endothelial lining 
and collagen fiber formation in the vessel wall, implying their potential in treating advanced lesions (75).

$\mathrm{C}$-reactive protein (CRP) is recognized as a predictive indicator of plaque instability because of its direct pro-inflammatory effects. CRP induces ECs to express various adhesion molecules and chemotactic molecules. CRP also stimulates monocytes to produce and secrete potent pro-coagulant factors promoting the inflammatory response $(130,131)$. Plasminogen activator inhibitor-1 (PAI-1) is a major inhibitor for fibrinolysis and an important risk factor for thrombotic diseases (132). In a rabbit advanced atherosclerosis model, MSCs transplantation dramatically decreases the expression of sensitive biomarkers for tissue damage, including CRP, MMPs, and PAI-1 (75). TNF- $\alpha$ promotes inflammatory cell accumulation in atherosclerotic plaques to negatively impact plaque stability and promote thrombosis and cell necrosis (133). IL-10, on the other hand, promotes lesion stability through inhibiting inflammatory cell accumulation and inducing SMC proliferation $(109,134,135)$. MSC transplantation effectively stabilizes vulnerable plaques in atherosclerotic rabbit model through immune modulation, as indicated by a reduction in TNF- $\alpha$ and IL- 6 and an increase in IL-10 in MSC-treated animals (79). Moreover, the expression of MMP-1, MMP-2, and MMP-9 in lesion is decreased after MSC transplantation, suggesting that alterations in MMPs may influence the extracellular matrix and further affect the lesion stability. These findings indicate that MSCs may alter plaque vulnerability by decreasing the regional collagen degradation via reduction of MMP synthesis. Furthermore, the cell apoptosis is one of the major features in atherosclerotic plaque $(136,137)$. In fact, the apoptosis of vascular ECs, vascular SMCs, and macrophages is involved in the formation, development, and rupture of atherosclerotic plaque (138). MSC transplantation dramatically decreases the number of apoptotic cells in plaques, suggesting that MSCs may increase the plaque stability also by inhibiting cell apoptosis (79).

\section{PITFALLS IN USING MSCs TO TREAT ATHEROSCLEROSIS}

Numerous clinical and preclinical trials have suggested that MSC transplantation is safe (139-141). The minimal and maximal dosages for therapeutic application has not been determined yet, but currently applied doses are in the range of $<1-5 \times 10^{6} \mathrm{MSCs} /$ $\mathrm{kg}$ body weight (142). Koç et al. have found that intravenously adoptive MSCs are well-tolerated in patients with mammary carcinoma at a dose of $1 \times 10^{6} \mathrm{MSCs} / \mathrm{kg}$ body weight (143). However, in animal models, allogeneic MSCs can be rejected by recipient mice although allogeneic MSCs show low immunogenicity (144). In addition, although preclinical and early phase clinical trials have not detected potential pitfalls of MSC therapy in human

\section{REFERENCES}

1. Lusis AJ. Atherosclerosis. Nature (2000) 407:233-41. doi:10.1038/35025203

2. Ni H, Coady S, Rosamond W, Folsom AR, Chambless L, Russell SD, et al. Trends from 1987 to 2004 in sudden death due to coronary heart disease: the Atherosclerosis Risk in Communities (ARIC) study. Am Heart J (2009) 157:46-52. doi:10.1016/j.ahj.2008.08.016 patients after MSC transplantation, tumor formation has been reported in several rodent models. BM-MSC transplantation may lead to the occurrence of gastric cancers (145). The chromosomal instability is also observed in mouse BM-MSCs that may lead to a malignant transformation (146). In October 2011, the experts in Cell Products Working Party have reached a consensus that good manufacturing practice conditions, such as cell preparation, culture, and manipulation, decrease the risk of tumorigenicity in MSC therapy. Cell culture condition and cell propagation duration significantly impact the formation of cytogenetic abnormalities (147).

\section{CONCLUSION AND PERSPECTIVE}

The major advantage of MSCs is their ability to migrate to sites of injury, respond dynamically to the extent of injury, and secrete a broad range of beneficial factors. These factors can modulate the inflammation status and restore endothelium function in atherosclerotic lesions. MSC transplantation represents a novel approach for efficient prevention and treatment of atherosclerotic plaque rupture. Studies on MSCs have provided theoretical and experimental evidence for its clinical application. However, there are no differences in atherosclerotic plaque burden after longterm observations in the MSC treatment group compared to controls, which indicates that the therapeutic effects of MSCs may not sustain for a long time after the removal of engrafted MSCs. To acquire persistent effects of MSCs, multiple treatments may be necessary. In addition, to effectively translate the current findings into clinic, future studies using mouse models with humanized immune system may be necessary, such as severe combined immunodeficiency (SCID), NOD/Shi-scid, IL-2R $\gamma$ null (NOG), or NOD/Lt-scid, IL-2R $\gamma$ null (NSG) mice.

Overall, much investigation remains to be done before understanding how MSCs are distributed and removed in the recipient, and whether their atheroprotecive effect is mediated through immunomodulation, or if the effectiveness of MSC therapy can be enhanced by various pretreatments with cocktails of different factors.

\section{AUTHOR CONTRIBUTIONS}

FL and XG wrote the review and S-YC revised the review.

\section{FUNDING}

This work was partially supported by grants from National Institutes of Health (HL135854, HL123302, and HL119053 to $\mathrm{S}-\mathrm{YC})$. XG is a recipient of American Heart Association Postdoctoral Fellowship (16POST27750038).

3. Baldassarre D, Castelnuovo S, Frigerio B, Amato M, Werba JP, De Jong A et al. Effects of timing and extent of smoking, type of cigarettes, and concomitant risk factors on the association between smoking and subclinical atherosclerosis. Stroke (2009) 40:1991-8. doi:10.1161/STROKEAHA.108. 543413

4. Dzubur A, Dzubur A, Mekic M. Tobacco smoking and obesity as risk factors of polyvascular atherosclerosis. Med Arh (2009) 63:90-3. 
5. Moran AE, Roth GA, Narula J, Mensah GA. 1990-2010 global cardiovascular disease atlas. Glob Heart (2014) 9:3-16. doi:10.1016/j.gheart.2014.03.1220

6. Tall AR. Plasma high density lipoproteins. Metabolism and relationship to atherogenesis. J Clin Invest (1990) 86:379-84. doi:10.1172/JCI114722

7. Jonasson L, Holm J, Skalli O, Bondjers G, Hansson GK. Regional accumulations of T cells, macrophages, and smooth muscle cells in the human atherosclerotic plaque. Arteriosclerosis (1986) 6:131-8. doi:10.1161/01.ATV.6.2.131

8. Antohe F. Endothelial cells and macrophages, partners in atherosclerotic plaque progression. Arch Physiol Biochem (2006) 112:245-53. doi:10.1080/13813450601094706

9. Libby P. Inflammation in atherosclerosis. Nature (2002) 420:868-74. doi:10.1038/nature01323

10. Tietge UJ. Hyperlipidemia and cardiovascular disease: inflammation, dyslipidemia, and atherosclerosis. Curr Opin Lipidol (2014) 25:94-5. doi:10.1097/ MOL.0000000000000051

11. Hermansson A, Ketelhuth DF, Strodthoff D, Wurm M, Hansson EM, Nicoletti A, et al. Inhibition of T cell response to native low-density lipoprotein reduces atherosclerosis. J Exp Med (2010) 207:1081-93. doi:10.1084/jem. 20092243

12. Hansson GK, Libby P. The immune response in atherosclerosis: a doubleedged sword. Nat Rev Immunol (2006) 6:508-19. doi:10.1038/nri1882

13. Klingenberg R, Hansson GK. Treating inflammation in atherosclerotic cardiovascular disease: emerging therapies. Eur Heart J (2009) 30:2838-44. doi:10.1093/eurheartj/ehp477

14. Gupta N, Su X, Popov B, Lee JW, Serikov V, Matthay MA. Intrapulmonary delivery of bone marrow-derived mesenchymal stem cells improves survival and attenuates endotoxin-induced acute lung injury in mice. J Immunol (2007) 179:1855-63. doi:10.4049/jimmunol.179.3.1855

15. Short B, Brouard N, Occhiodoro-Scott T, Ramakrishnan A, Simmons PJ. Mesenchymal stem cells. Arch Med Res (2003) 34:565-71. doi:10.1016/j. arcmed.2003.09.007

16. Hass R, Kasper C, Bohm S, Jacobs R. Different populations and sources of human mesenchymal stem cells (MSC): a comparison of adult and neonatal tissue-derived MSC. Cell Commun Signal (2011) 9:12. doi:10.1186/ 1478-811X-9-12

17. Ortiz LA, Dutreil M, Fattman C, Pandey AC, Torres G, Go K, et al. Interleukin 1 receptor antagonist mediates the antiinflammatory and antifibrotic effect of mesenchymal stem cells during lung injury. Proc Natl Acad Sci U S A (2007) 104:11002-7. doi:10.1073/pnas.0704421104

18. Lee RH, Pulin AA, Seo MJ, Kota DJ, Ylostalo J, Larson BL, et al. Intravenous hMSCs improve myocardial infarction in mice because cells embolized in lung are activated to secrete the anti-inflammatory protein TSG-6. Cell Stem Cell (2009) 5:54-63. doi:10.1016/j.stem.2009.05.003

19. Togel F, Hu Z, Weiss K, Isaac J, Lange C, Westenfelder C. Administered mesenchymal stem cells protect against ischemic acute renal failure through differentiation-independent mechanisms. Am J Physiol Renal Physiol (2005) 289:F31-42. doi:10.1152/ajprenal.00007.2005

20. Sheikh AM, Nagai A, Wakabayashi K, Narantuya D, Kobayashi S, Yamaguchi S, et al. Mesenchymal stem cell transplantation modulates neuroinflammation in focal cerebral ischemia: contribution of fractalkine and IL-5. Neurobiol Dis (2011) 41:717-24. doi:10.1016/j.nbd.2010.12.009

21. Lee JK, Jin HK, Endo S, Schuchman EH, Carter JE, Bae JS. Intracerebral transplantation of bone marrow-derived mesenchymal stem cells reduces amyloid-beta deposition and rescues memory deficits in Alzheimer's disease mice by modulation of immune responses. Stem Cells (2010) 28:329-43. doi:10.1002/stem.277

22. Yao L, Li ZR, Su WR, Li YP, Lin ML, Zhang WX, et al. Role of mesenchymal stem cells on cornea wound healing induced by acute alkali burn. PLoS One (2012) 7:e30842. doi:10.1371/journal.pone.0030842

23. Minguell JJ, Erices A, Conget P. Mesenchymal stem cells. Exp Biol Med (Maywood) (2001) 226:507-20.

24. Pittenger MF, Mackay AM, Beck SC, Jaiswal RK, Douglas R, Mosca JD, et al. Multilineage potential of adult human mesenchymal stem cells. Science (1999) 284:143-7. doi:10.1126/science.284.5411.143

25. Karantalis V, Balkan W, Schulman IH, Hatzistergos KE, Hare JM. Cell-based therapy for prevention and reversal of myocardial remodeling. Am J Physiol Heart Circ Physiol (2012) 303:H256-70. doi:10.1152/ajpheart.00221.2012
26. Friedenstein AJ, Gorskaja JF, Kulagina NN. Fibroblast precursors in normal and irradiated mouse hematopoietic organs. Exp Hematol (1976) 4:267-74.

27. Romanov YA, Svintsitskaya VA, Smirnov VN. Searching for alternative sources of postnatal human mesenchymal stem cells: candidate MSC-like cells from umbilical cord. Stem Cells (2003) 21:105-10. doi:10.1634/ stemcells.21-1-105

28. Kuhbier JW, Weyand B, Radtke C, Vogt PM, Kasper C, Reimers K. Isolation, characterization, differentiation, and application of adipose-derived stem cells. Adv Biochem Eng Biotechnol (2010) 123:55-105. doi:10.1007/10_2009_24

29. Kern S, Eichler H, Stoeve J, Kluter H, Bieback K. Comparative analysis of mesenchymal stem cells from bone marrow, umbilical cord blood, or adipose tissue. Stem Cells (2006) 24:1294-301. doi:10.1634/stemcells.2005-0342

30. Choi YH, Kurtz A, Stamm C. Mesenchymal stem cells for cardiac cell therapy. Hum Gene Ther (2011) 22:3-17. doi:10.1089/hum.2010.211

31. Lennon DP, Caplan AI. Isolation of human marrow-derived mesenchymal stem cells. Exp Hematol (2006) 34:1604-5. doi:10.1016/j.exphem.2006.07.015

32. Schallmoser K, Rohde E, Reinisch A, Bartmann C, Thaler D, Drexler C, et al. Rapid large-scale expansion of functional mesenchymal stem cells from unmanipulated bone marrow without animal serum. Tissue Eng Part C Methods (2008) 14:185-96. doi:10.1089/ten.tec.2008.0060

33. Dominici M, Le Blanc K, Mueller I, Slaper-Cortenbach I, Marini F, Krause D, et al. Minimal criteria for defining multipotent mesenchymal stromal cells. The International Society for Cellular Therapy position statement. Cytotherapy (2006) 8:315-7. doi:10.1080/14653240600855905

34. Bobis S, Jarocha D, Majka M. Mesenchymal stem cells: characteristics and clinical applications. Folia Histochem Cytobiol (2006) 44:215-30.

35. Djouad F, Bony C, Häupl T, Uzé G, Lahlou N, Louis-Plence P, et al. Transcriptional profiles discriminate bone marrow-derived and synovium-derived mesenchymal stem cells. Arthritis Res Ther (2005) 7:R1304-15. doi:10.1186/ar1573

36. Chamberlain G, Fox J, Ashton B, Middleton J. Concise review: mesenchymal stem cells: their phenotype, differentiation capacity, immunological features, and potential for homing. Stem Cells (2007) 25:2739-49. doi:10.1634/ stemcells.2007-0197

37. Mareschi K, Biasin E, Piacibello W, Aglietta M, Madon E, Fagioli F. Isolation of human mesenchymal stem cells: bone marrow versus umbilical cord blood. Haematologica (2001) 86:1099-100.

38. Huss R. Isolation of primary and immortalized CD34-hematopoietic and mesenchymal stem cells from various sources. Stem Cells (2000) 18:1-9. doi:10.1634/stemcells.18-1-1

39. Hows JM. Status of umbilical cord blood transplantation in the year 2001. J Clin Pathol (2001) 54:428-34. doi:10.1136/jcp.54.6.428

40. Devine SM, Bartholomew AM, Mahmud N, Nelson M, Patil S, Hardy W, et al. Mesenchymal stem cells are capable of homing to the bone marrow of non-human primates following systemic infusion. Exp Hematol (2001) 29:244-55. doi:10.1016/S0301-472X(00)00635-4

41. Devine SM, Cobbs C, Jennings M, Bartholomew A, Hoffman R. Mesenchymal stem cells distribute to a wide range of tissues following systemic infusion into nonhuman primates. Blood (2003) 101:2999-3001. doi:10.1182/ blood-2002-06-1830

42. Gao J, Dennis JE, Muzic RF, Lundberg M, Caplan AI. The dynamic in vivo distribution of bone marrow-derived mesenchymal stem cells after infusion. Cells Tissues Organs (2001) 169:12-20. doi:10.1159/000047856

43. Barbash IM, Chouraqui P, Baron J, Feinberg MS, Etzion S, Tessone A, et al. Systemic delivery of bone marrow-derived mesenchymal stem cells to the infarcted myocardium: feasibility, cell migration, and body distribution. Circulation (2003) 108:863-8. doi:10.1161/01.CIR.0000084828.50310.6A

44. Kraitchman DL, Tatsumi M, Gilson WD, Ishimori T, Kedziorek D, Walczak P, et al. Dynamic imaging of allogeneic mesenchymal stem cells trafficking to myocardial infarction. Circulation (2005) 112:1451-61. doi:10.1161/CIRCULATIONAHA.105.537480

45. Park SE, Jung NY, Lee NK, Lee J, Hyung B, Myeong SH, et al. Distribution of human umbilical cord blood-derived mesenchymal stem cells (hUCBMSCs) in canines after intracerebroventricular injection. Neurobiol Aging (2016) 47:192-200. doi:10.1016/j.neurobiolaging.2016.08.002

46. Joo SY, Cho KA, Jung YJ, Kim HS, Park SY, Choi YB, et al. Bioimaging for the monitoring of the in vivo distribution of infused mesenchymal stem cells in a 
mouse model of the graft-versus-host reaction. Cell Biol Int (2011) 35:417-21. doi:10.1042/CBI20100563

47. Liao X, Li F, Wang X, Yanoso J, Niyibizi C. Distribution of murine adiposederived mesenchymal stem cells in vivo following transplantation in developing mice. Stem Cells Dev (2008) 17:303-14. doi:10.1089/scd.2007.0086

48. Ip JE, Wu Y, Huang J, Zhang L, Pratt RE, Dzau VJ. Mesenchymal stem cells use integrin beta1 not CXC chemokine receptor 4 for myocardial migration and engraftment. Mol Biol Cell (2007) 18:2873-82. doi:10.1091/mbc.E07-02-0166

49. Segers VF, Van Riet I, Andries LJ, Lemmens K, Demolder MJ, De Becker AJ, et al. Mesenchymal stem cell adhesion to cardiac microvascular endothelium: activators and mechanisms. Am J Physiol Heart Circ Physiol (2006) 290:H1370-7. doi:10.1152/ajpheart.00523.2005

50. Wu Y, Zhao RC. The role of chemokines in mesenchymal stem cell homing to myocardium. Stem Cell Rev (2012) 8:243-50. doi:10.1007/s12015-011-9293-Z

51. Belema-Bedada F, Uchida S, Martire A, Kostin S, Braun T. Efficient homing of multipotent adult mesenchymal stem cells depends on FROUNTmediated clustering of CCR2. Cell Stem Cell (2008) 2:566-75. doi:10.1016/j. stem.2008.03.003

52. Yilmaz G, Vital S, Yilmaz CE, Stokes KY, Alexander JS, Granger DN. Selectin-mediated recruitment of bone marrow stromal cells in the postischemic cerebral microvasculature. Stroke (2011) 42:806-11. doi:10.1161/ STROKEAHA.110.597088

53. Toma C, Wagner WR, Bowry S, Schwartz A, Villanueva F. Fate of cultureexpanded mesenchymal stem cells in the microvasculature: in vivo observations of cell kinetics. Circ Res (2009) 104:398-402. doi:10.1161/ CIRCRESAHA.108.187724

54. Cui LL, Kerkela E, Bakreen A, Nitzsche F, Andrzejewska A, Nowakowski A, et al. The cerebral embolism evoked by intra-arterial delivery of allogeneic bone marrow mesenchymal stem cells in rats is related to cell dose and infusion velocity. Stem Cell Res Ther (2015) 6:11. doi:10.1186/scrt544

55. Di Nicola M, Carlo-Stella C, Magni M, Milanesi M, Longoni PD, Matteucci P, et al. Human bone marrow stromal cells suppress T-lymphocyte proliferation induced by cellular or nonspecific mitogenic stimuli. Blood (2002) 99:3838-43. doi:10.1182/blood.V99.10.3838

56. Tse WT, Pendleton JD, Beyer WM, Egalka MC, Guinan EC. Suppression of allogeneic T-cell proliferation by human marrow stromal cells: implications in transplantation. Transplantation (2003) 75:389-97. doi:10.1097/01. TP.0000045055.63901.A9

57. von Bubnoff D, Bieber T. The indoleamine 2,3-dioxygenase (IDO) pathway controls allergy. Allergy (2012) 67:718-25. doi:10.1111/j.1398-9995.2012. 02830.x

58. Munn DH, Mellor AL. Indoleamine 2,3 dioxygenase and metabolic control of immune responses. Trends Immunol (2013) 34:137-43. doi:10.1016/j. it.2012.10.001

59. Zhang W, Ge W, Li C, You S, Liao L, Han Q, et al. Effects of mesenchymal stem cells on differentiation, maturation, and function of human monocyte-derived dendritic cells. Stem Cells Dev (2004) 13:263-71. doi:10.1089/154732804323099190

60. Spaggiari GM, Capobianco A, Abdelrazik H, Becchetti F, Mingari MC, Moretta L. Mesenchymal stem cells inhibit natural killer-cell proliferation, cytotoxicity, and cytokine production: role of indoleamine 2,3-dioxygenase and prostaglandin E2. Blood (2008) 111:1327-33. doi:10.1182/ blood-2007-02-074997

61. Aggarwal S, Pittenger MF. Human mesenchymal stem cells modulate allogeneic immune cell responses. Blood (2005) 105:1815-22. doi:10.1182/ blood-2004-04-1559

62. Ghannam S, Pene J, Moquet-Torcy G, Jorgensen C, Yssel H. Mesenchymal stem cells inhibit human Th17 cell differentiation and function and induce a T regulatory cell phenotype. J Immunol (2010) 185:302-12. doi:10.4049/ jimmunol.0902007

63. Augello A, Tasso R, Negrini SM, Amateis A, Indiveri F, Cancedda R, et al. Bone marrow mesenchymal progenitor cells inhibit lymphocyte proliferation by activation of the programmed death 1 pathway. Eur J Immunol (2005) 35:1482-90. doi:10.1002/eji.200425405

64. Rashedi I, Gomez-AristizAbal A, Wang XH, Viswanathan S, Keating A. TLR3 or TLR4 activation enhances mesenchymal stromal cell-mediated Treg induction via notch signaling. Stem Cells (2017) 35:265-75. doi:10.1002/ stem. 2485
65. Hansson GK. Inflammation, atherosclerosis, and coronary artery disease. N Engl J Med (2005) 352:1685-95. doi:10.1056/NEJMra043430

66. Li H, Cybulsky MI, Gimbrone MA Jr, Libby P. An atherogenic diet rapidly induces VCAM-1, a cytokine-regulatable mononuclear leukocyte adhesion molecule, in rabbit aortic endothelium. Arterioscler Thromb (1993) 13:197-204. doi:10.1161/01.ATV.13.2.197

67. Wagner DD, Frenette PS. The vessel wall and its interactions. Blood (2008) 111:5271-81. doi:10.1182/blood-2008-01-078204

68. Weber C, Zernecke A, Libby P. The multifaceted contributions of leukocyte subsets to atherosclerosis: lessons from mouse models. Nat Rev Immunol (2008) 8:802-15. doi:10.1038/nri2415

69. Emeson EE, Shen ML, Bell CG, Qureshi A. Inhibition of atherosclerosis in CD4 T-cell-ablated and nude (nu/nu) C57BL/6 hyperlipidemic mice. Am J Pathol (1996) 149:675-85.

70. Frostegard J, Ulfgren AK, Nyberg P, Hedin U, Swedenborg J, Andersson U, et al. Cytokine expression in advanced human atherosclerotic plaques: dominance of pro-inflammatory (Th1) and macrophage-stimulating cytokines. Atherosclerosis (1999) 145:33-43. doi:10.1016/S0021-9150(99)00011-8

71. Zhou X, Paulsson G, Stemme S, Hansson GK. Hypercholesterolemia is associated with a $\mathrm{T}$ helper (Th) $1 / \mathrm{Th} 2$ switch of the autoimmune response in atherosclerotic apo E-knockout mice. J Clin Invest (1998) 101:1717-25. doi:10.1172/JCI1216

72. Voloshyna I, Littlefield MJ, Reiss AB. Atherosclerosis and interferon-gamma: new insights and therapeutic targets. Trends Cardiovasc Med (2014) 24:45-51. doi:10.1016/j.tcm.2013.06.003

73. Schu S, Nosov M, O'Flynn L, Shaw G, Treacy O, Barry F, et al. Immunogenicity of allogeneic mesenchymal stem cells. J Cell Mol Med (2012) 16:2094-103. doi:10.1111/j.1582-4934.2011.01509.x

74. Gebler A, Zabel O, Seliger B. The immunomodulatory capacity of mesenchymal stem cells. Trends Mol Med (2012) 18:128-34. doi:10.1016/j. molmed.2011.10.004

75. Fang SM, Du DY, Li YT, Ge XL, Qin PT, Zhang QH, et al. Allogeneic bone marrow mesenchymal stem cells transplantation for stabilizing and repairing of atherosclerotic ruptured plaque. Thromb Res (2013) 131:e253-7. doi:10.1016/j.thromres.2013.04.002

76. Wang ZX, Wang CQ, Li XY, Feng GK, Zhu HL, Ding Y, et al. Mesenchymal stem cells alleviate atherosclerosis by elevating number and function of CD4(+)CD25 (+)FOXP3 (+) regulatory T-cells and inhibiting macrophage foam cell formation. Mol Cell Biochem (2015) 400:163-72. doi:10.1007/ s11010-014-2272-3

77. Lin YL, Yet SF, Hsu YT, Wang GJ, Hung SC. Mesenchymal stem cells ameliorate atherosclerotic lesions via restoring endothelial function. Stem Cells Transl Med (2015) 4:44-55. doi:10.5966/sctm.2014-0091

78. Frodermann V, van Duijn J, van Pel M, van Santbrink PJ, Bot I, Kuiper J, et al. Mesenchymal stem cells reduce murine atherosclerosis development. Sci Rep (2015) 5:15559. doi:10.1038/srep15559

79. Wang SS, Hu SW, Zhang QH, Xia AX, Jiang ZX, Chen XM. Mesenchymal stem cells stabilize atherosclerotic vulnerable plaque by anti-inflammatory properties. PLoS One (2015) 10:e0136026. doi:10.1371/journal.pone.0136026

80. Abdel-Kawi SH, Hashem KS. Possible therapeutic effect of stem cell in atherosclerosis in Albino rats. A histological and immunohistochemical study. Int J Stem Cells (2015) 8:200-8. doi:10.15283/ijsc.2015.8.2.200

81. Li Q, Sun W, Wang X, Zhang K, Xi W, Gao P. Skin-derived mesenchymal stem cells alleviate atherosclerosis via modulating macrophage function. Stem Cells Transl Med (2015) 4:1294-301. doi:10.5966/sctm.2015-0020

82. English K, Ryan JM, Tobin L, Murphy MJ, Barry FP, Mahon BP. Cell contact, prostaglandin $\mathrm{E}(2)$ and transforming growth factor beta 1 play nonredundant roles in human mesenchymal stem cell induction of CD4+CD25(High) forkhead box P3+ regulatory T cells. Clin Exp Immunol (2009) 156:149-60. doi:10.1111/j.1365-2249.2009.03874.x

83. Sotiropoulou PA, Perez SA, Gritzapis AD, Baxevanis CN, Papamichail M. Interactions between human mesenchymal stem cells and natural killer cells. Stem Cells (2006) 24:74-85. doi:10.1634/stemcells.2004-0359

84. Han X, Boisvert WA. Interleukin-10 protects against atherosclerosis by modulating multiple atherogenic macrophage function. Thromb Haemost (2015) 113:505-12. doi:10.1160/TH14-06-0509

85. Du YY, Zhou SH, Zhou T, Su H, Pan HW, Du WH, et al. Immunoinflammatory regulation effect of mesenchymal stem cell transplantation 
in a rat model of myocardial infarction. Cytotherapy (2008) 10:469-78. doi:10.1080/14653240802129893

86. van Buul GM, Villafuertes E, Bos PK, Waarsing JH, Kops N, Narcisi R, et al. Mesenchymal stem cells secrete factors that inhibit inflammatory processes in short-term osteoarthritic synovium and cartilage explant culture. Osteoarthritis Cartilage (2012) 20:1186-96. doi:10.1016/j.joca.2012.06.003

87. Jungebluth P, Luedde M, Ferrer E, Luedde T, Vucur M, Peinado VI, et al. Mesenchymal stem cells restore lung function by recruiting resident and nonresident proteins. Cell Transplant (2011) 20:1561-74. doi:10.3727/0963 68910X557254

88. Prockop DJ, Oh JY. Mesenchymal stem/stromal cells (MSCs): role as guardians of inflammation. Mol Ther (2012) 20:14-20. doi:10.1038/mt.2011.211

89. Liu YJ, Kanzler H, Soumelis V, Gilliet M. Dendritic cell lineage, plasticity and cross-regulation. Nat Immunol (2001) 2:585-9. doi:10.1038/89726

90. Baratelli F, Lin Y, Zhu L, Yang SC, Heuze-Vourc'h N, Zeng G, et al. Prostaglandin E2 induces FOXP3 gene expression and T regulatory cell function in human CD4+ T cells. J Immunol (2005) 175:1483-90. doi:10.4049/ jimmunol.175.3.1483

91. Choi H, Lee RH, Bazhanov N, Oh JY, Prockop DJ. Anti-inflammatory protein TSG-6 secreted by activated MSCs attenuates zymosan-induced mouse peritonitis by decreasing TLR2/NF-kappaB signaling in resident macrophages. Blood (2011) 118:330-8. doi:10.1182/blood-2010-12-327353

92. Wisniewski HG, Maier R, Lotz M, Lee S, Klampfer L, Lee TH, et al. TSG-6: a TNF-, IL-1-, and LPS-inducible secreted glycoprotein associated with arthritis. J Immunol (1993) 151:6593-601.

93. Wisniewski HG, Hua JC, Poppers DM, Naime D, Vilcek J, Cronstein BN. TNF/IL-1-inducible protein TSG-6 potentiates plasmin inhibition by inter-alpha-inhibitor and exerts a strong anti-inflammatory effect in vivo. J Immunol (1996) 156:1609-15.

94. Cao TV, La M, Getting SJ, Day AJ, Perretti M. Inhibitory effects of TSG-6 Link module on leukocyte-endothelial cell interactions in vitro and in vivo. Microcirculation (2004) 11:615-24. doi:10.1080/10739680490503438

95. Luscher TF, Barton M. Biology of the endothelium. Clin Cardiol (1997) 20:II-3-10.

96. Forstermann U, Munzel T. Endothelial nitric oxide synthase in vascular disease: from marvel to menace. Circulation (2006) 113:1708-14. doi:10.1161/ CIRCULATIONAHA.105.602532

97. Félétou M. The Endothelium: Part 1: Multiple Functions of the Endothelial Cells - Focus on Endothelium-Derived Vasoactive Mediators. San Rafael, CA: Morgan \& Claypool Life Sciences (2011). 281 p.

98. De Caterina R, Libby P, Peng HB, Thannickal VJ, Rajavashisth TB, Gimbrone MA Jr, et al. Nitric oxide decreases cytokine-induced endothelial activation. Nitric oxide selectively reduces endothelial expression of adhesion molecules and proinflammatory cytokines. JClin Invest (1995) 96:60-8. doi:10.1172/JCI1 18074

99. Konig J, Huppertz B, Desoye G, Parolini O, Frohlich JD, Weiss G, et al. Amnion-derived mesenchymal stromal cells show angiogenic properties but resist differentiation into mature endothelial cells. Stem Cells Dev (2012) 21:1309-20. doi:10.1089/scd.2011.0223

100. von Boehmer H. Mechanisms of suppression by suppressor T cells. Nat Immunol (2005) 6:338-44. doi:10.1038/ni1180

101. Nakamura K, Kitani A, Strober W. Cell contact-dependent immunosuppression by $\mathrm{CD} 4(+) \mathrm{CD} 25(+)$ regulatory $\mathrm{T}$ cells is mediated by cell surface-bound transforming growth factor beta. J Exp Med (2001) 194:629-44. doi:10.1084/ jem.194.5.629

102. Hori S, Nomura T, Sakaguchi S. Control of regulatory T cell development by the transcription factor Foxp3. Science (2003) 299:1057-61. doi:10.1126/ science. 1079490

103. Fontenot JD, Gavin MA, Rudensky AY. Foxp3 programs the development and function of CD4+CD25+ regulatory T cells. Nat Immunol (2003) 4:330-6. doi: $10.1038 /$ ni904

104. Shevach EM. From vanilla to 28 flavors: multiple varieties of T regulatory cells. Immunity (2006) 25:195-201. doi:10.1016/j.immuni.2006.08.003

105. Chistiakov DA, Sobenin IA, Orekhov AN. Regulatory T cells in atherosclerosis and strategies to induce the endogenous atheroprotective immune response. Immunol Lett (2013) 151:10-22. doi:10.1016/j.imlet.2013.01.014

106. Sardella G, De Luca L, Francavilla V, Accapezzato D, Mancone M, Sirinian MI, et al. Frequency of naturally-occurring regulatory $\mathrm{T}$ cells is reduced in patients with ST-segment elevation myocardial infarction. Thromb Res (2007) 120:631-4. doi:10.1016/j.thromres.2006.12.005

107. Klingenberg R, Gerdes N, Badeau RM, Gistera A, Strodthoff D, Ketelhuth DF, et al. Depletion of FOXP3+ regulatory T cells promotes hypercholesterolemia and atherosclerosis. J Clin Invest (2013) 123:1323-34. doi:10.1172/JCI63891

108. Ait-Oufella H, Salomon BL, Potteaux S, Robertson AK, Gourdy P, Zoll J, et al. Natural regulatory $\mathrm{T}$ cells control the development of atherosclerosis in mice. Nat Med (2006) 12:178-80. doi:10.1038/nm1343

109. Mallat Z, Besnard S, Duriez M, Deleuze V, Emmanuel F, Bureau MF, et al. Protective role of interleukin-10 in atherosclerosis. Circ Res (1999) 85:e17-24. doi:10.1161/01.RES.85.8.e17

110. Pinderski LJ, Fischbein MP, Subbanagounder G, Fishbein MC, Kubo N, Cheroutre $\mathrm{H}$, et al. Overexpression of interleukin-10 by activated $\mathrm{T}$ lymphocytes inhibits atherosclerosis in LDL receptor-deficient mice by altering lymphocyte and macrophage phenotypes. Circ Res (2002) 90:1064-71. doi:10.1161/01.RES.0000018941.10726.FA

111. Robertson AK, Rudling M, Zhou X, Gorelik L, Flavell RA, Hansson GK. Disruption of TGF-beta signaling in T cells accelerates atherosclerosis. J Clin Invest (2003) 112:1342-50. doi:10.1172/JCI18607

112. Gojova A, Brun V, Esposito B, Cottrez F, Gourdy P, Ardouin P, et al. Specific abrogation of transforming growth factor-beta signaling in T cells alters atherosclerotic lesion size and composition in mice. Blood (2003) 102:4052-8. doi:10.1182/blood-2003-05-1729

113. Foks AC, Frodermann V, ter Borg M, Habets KL, Bot I, Zhao Y, et al. Differential effects of regulatory $\mathrm{T}$ cells on the initiation and regression of atherosclerosis. Atherosclerosis (2011) 218:53-60. doi:10.1016/j.atherosclerosis.2011.04.029

114. Melief SM, Schrama E, Brugman MH, Tiemessen MM, Hoogduijn MJ, Fibbe WE, et al. Multipotent stromal cells induce human regulatory T cells through a novel pathway involving skewing of monocytes toward antiinflammatory macrophages. Stem Cells (2013) 31:1980-91. doi:10.1002/ stem. 1432

115. Cahill EF, Tobin LM, Carty F, Mahon BP, English K. Jagged-1 is required for the expansion of $\mathrm{CD} 4+\mathrm{CD} 25+$ FoxP3+ regulatory $\mathrm{T}$ cells and tolerogenic dendritic cells by murine mesenchymal stromal cells. Stem Cell Res Ther (2015) 6:19. doi:10.1186/s13287-015-0021-5

116. Alhadlaq A, Mao JJ. Mesenchymal stem cells: isolation and therapeutics. Stem Cells Dev (2004) 13:436-48. doi:10.1089/scd.2004.13.436

117. Martins AR, Zanella CA, Zucchi FC, Dombroski TC, Costa ET, Guethe LM, et al. Immunolocalization of nitric oxide synthase isoforms in human archival and rat tissues, and cultured cells. J Neurosci Methods (2011) 198:16-22. doi:10.1016/j.jneumeth.2011.02.024

118. de Boer HC, Verseyden C, Ulfman LH, Zwaginga JJ, Bot I, Biessen EA, et al. Fibrin and activated platelets cooperatively guide stem cells to a vascular injury and promote differentiation towards an endothelial cell phenotype. Arterioscler Thromb Vasc Biol (2006) 26:1653-9. doi:10.1161/01. ATV.0000222982.55731.f1

119. Chin-Dusting JP, Shaw JA. Lipids and atherosclerosis: clinical management of hypercholesterolaemia. Expert Opin Pharmacother (2001) 2:419-30. doi:10.1517/14656566.2.3.419

120. Reardon CA, Blachowicz L, Lukens J, Nissenbaum M, Getz GS. Genetic background selectively influences innominate artery atherosclerosis: immune system deficiency as a probe. Arterioscler Thromb Vasc Biol (2003) 23:1449-54. doi:10.1161/01.ATV.0000079793.58054.2E

121. Bartolome N, Arteta B, Martinez MJ, Chico Y, Ochoa B. Kupffer cell products and interleukin lbeta directly promote VLDL secretion and apoB mRNA up-regulation in rodent hepatocytes. Innate Immun (2008) 14:255-66. doi:10.1177/1753425908094718

122. Babaev VR, Fazio S, Gleaves LA, Carter KJ, Semenkovich CF, Linton MF. Macrophage lipoprotein lipase promotes foam cell formation and atherosclerosis in vivo. J Clin Invest (1999) 103:1697-705. doi:10.1172/JCI6117

123. Van Eck M, Zimmermann R, Groot PH, Zechner R, Van Berkel TJ. Role of macrophage-derived lipoprotein lipase in lipoprotein metabolism and atherosclerosis. Arterioscler Thromb Vasc Biol (2000) 20:E53-62. doi:10.1161/ 01.ATV.20.9.e53

124. Ruan H, Miles PD, Ladd CM, Ross K, Golub TR, Olefsky JM, et al. Profiling gene transcription in vivo reveals adipose tissue as an immediate target of tumor necrosis factor-alpha: implications for insulin resistance. Diabetes (2002) 51:3176-88. doi:10.2337/diabetes.51.11.3176 
125. von der Thüsen JH, Kuiper J, Fekkes ML, de Vos P, van Berkel TJC, Biessen EAL. Attenuation of atherogenesis by systemic and local adenovirus-mediated gene transfer of interleukin-10 in $\mathrm{LDLR}^{-/-}$mice. FASEB J (2001) 15(14):2730-2. doi:10.1096/fj.01-0483fje

126. Virmani R, Kolodgie FD, Burke AP, Farb A, Schwartz SM. Lessons from sudden coronary death: a comprehensive morphological classification scheme for atherosclerotic lesions. Arterioscler Thromb Vasc Biol (2000) 20:1262-75. doi:10.1161/01.ATV.20.5.1262

127. Spagnoli LG, Mauriello A, Sangiorgi G, Fratoni S, Bonanno E, Schwartz RS, et al. Extracranial thrombotically active carotid plaque as a risk factor for ischemic stroke. JAMA (2004) 292:1845-52. doi:10.1001/jama.292.15.1845

128. Burke AP, Farb A, Malcom GT, Liang YH, Smialek J, Virmani R. Coronary risk factors and plaque morphology in men with coronary disease who died suddenly. N Engl J Med (1997) 336:1276-82. doi:10.1056/ NEJM199705013361802

129. Redgrave JN, Lovett JK, Gallagher PJ, Rothwell PM. Histological assessment of 526 symptomatic carotid plaques in relation to the nature and timing of ischemic symptoms: the Oxford plaque study. Circulation (2006) 113:2320-8. doi:10.1161/CIRCULATIONAHA.105.589044

130. Guo S, Meng S, Chen B, Liu J, Gao L, Wu Y. C-reactive protein can influence the proliferation, apoptosis, and monocyte chemotactic protein-1 production of human umbilical vein endothelial cells. DNA Cell Biol (2011) 30:157-62. doi:10.1089/dna.2010.1093

131. Forte L, Cimmino G, Loffredo F, De Palma R, Abbate G, Calabro P, et al. $\mathrm{C}$-reactive protein is released in the coronary circulation and causes endothelial dysfunction in patients with acute coronary syndromes. Int J Cardiol (2011) 152:7-12. doi:10.1016/j.ijcard.2011.05.062

132. Haverkate F. Levels of haemostatic factors, arteriosclerosis and cardiovascular disease. Vascul Pharmacol (2002) 39:109-12. doi:10.1016/ S1537-1891(02)00295-1

133. Kleemann R, Zadelaar S, Kooistra T. Cytokines and atherosclerosis: a comprehensive review of studies in mice. Cardiovasc Res (2008) 79:360-76. doi:10.1093/cvr/cvn120

134. Heeschen C, DimmelerS, Hamm CW,FichtlschererS, BoersmaE, Simoons ML, et al. Serum level of the antiinflammatory cytokine interleukin-10 is an important prognostic determinant in patients with acute coronary syndromes. Circulation (2003) 107:2109-14. doi:10.1161/01.CIR.0000048183. 37648.1A

135. Potteaux S, Esposito B, van Oostrom O, Brun V, Ardouin P, Groux H, et al. Leukocyte-derived interleukin 10 is required for protection against atherosclerosis in low-density lipoprotein receptor knockout mice. Arterioscler Thromb Vasc Biol (2004) 24:1474-8. doi:10.1161/01.ATV.0000134378. 86443.cd

136. Rossig L, Dimmeler S, Zeiher AM. Apoptosis in the vascular wall and atherosclerosis. Basic Res Cardiol (2001) 96:11-22. doi:10.1007/s003950170073

137. Mallat Z, Tedgui A. Apoptosis in the vasculature: mechanisms and functional importance. Br J Pharmacol (2000) 130:947-62. doi:10.1038/sj.bjp. 0703407
138. Li Y, Gerbod-Giannone MC, Seitz H, Cui D, Thorp E, Tall AR, et al. Cholesterol-induced apoptotic macrophages elicit an inflammatory response in phagocytes, which is partially attenuated by the Mer receptor. J Biol Chem (2006) 281:6707-17. doi:10.1074/jbc.M510579200

139. Reinders ME, deFijterJW, RoelofsH,BajemaIM,deVriesDK,SchaapherderAF, et al. Autologous bone marrow-derived mesenchymal stromal cells for the treatment of allograft rejection after renal transplantation: results of a phase I study. Stem Cells Transl Med (2013) 2:107-11. doi:10.5966/sctm.2012-0114

140. Peng Y, Ke M, Xu L, Liu L, Chen X, Xia W, et al. Donor-derived mesenchymal stem cells combined with low-dose tacrolimus prevent acute rejection after renal transplantation: a clinical pilot study. Transplantation (2013) 95:161-8. doi:10.1097/TP.0b013e3182754c53

141. Mudrabettu C, Kumar V, Rakha A, Yadav AK, Ramachandran R, Kanwar DB, et al. Safety and efficacy of autologous mesenchymal stromal cells transplantation in patients undergoing living donor kidney transplantation: a pilot study. Nephrology (Carlton) (2015) 20:25-33. doi:10.1111/nep.12338

142. Subbanna PK. Mesenchymal stem cells for treating GVHD: in-vivo fate and optimal dose. Med Hypotheses (2007) 69:469-70. doi:10.1016/j. mehy.2006.12.016

143. Koç ON, Gerson SL, Cooper BW, Dyhouse SM, Haynesworth SE, Caplan AI, et al. Rapid hematopoietic recovery after coinfusion of autologous-blood stem cells and culture-expanded marrow mesenchymal stem cells in advanced breast cancer patients receiving high-dose chemotherapy. J Clin Oncol (2000) 18:307-16. doi:10.1200/JCO.2000.18.2.307

144. Uccelli A, Moretta L, Pistoia V. Mesenchymal stem cells in health and disease. Nat Rev Immunol (2008) 8:726-36. doi:10.1038/nri2395

145. Houghton J, Stoicov C, Nomura S, Rogers AB, Carlson J, Li H, et al. Gastric cancer originating from bone marrow-derived cells. Science (2004) 306:1568-71. doi:10.1126/science.1099513

146. Miura M, Miura Y, Padilla-Nash HM, Molinolo AA, Fu B, Patel V, et al. Accumulated chromosomal instability in murine bone marrow mesenchymal stem cells leads to malignant transformation. Stem Cells (2006) 24:1095-103. doi:10.1634/stemcells.2005-0403

147. Barkholt L, Flory E, Jekerle V, Lucas-Samuel S, Ahnert P, Bisset L, et al. Risk of tumorigenicity in mesenchymal stromal cell-based therapies - bridging scientific observations and regulatory viewpoints. Cytotherapy (2013) 15:753-9. doi:10.1016/j.jcyt.2013.03.005

Conflict of Interest Statement: The authors declare that the research was conducted in the absence of any commercial or financial relationships that could be construed as a potential conflict of interest.

Copyright (C) 2017 Li, Guo and Chen. This is an open-access article distributed under the terms of the Creative Commons Attribution License (CC BY). The use, distribution or reproduction in other forums is permitted, provided the original author(s) or licensor are credited and that the original publication in this journal is cited, in accordance with accepted academic practice. No use, distribution or reproduction is permitted which does not comply with these terms. 